Observations over a period of six months show that it is at least as effective as the usual method. The saving in nursing time and labour justifies its continued use. The cost of treatment is low.

Further trials are in progress.

My thanks are due to Dr. A. B. Pollard for permission to conduct this survey on patients in his beds, and for advice and criticism; and to Miss F. Goodall, S.R.N., S.C.M., who has supervised the treatment since its introduction.

\section{HAZARDS OF THE MENSTRUAL CYCLE} BY

\section{P. C. B. MacKINNON, M.B., B.S.}

Middlesex Hospital Medical School, London AND

\section{L. MacKINNON, M.B., Ch.B. King's College, Strand, London}

The luteal phase of the menstrual cycle occupies on an average the 14 days preceding menstrual bleeding and is conventionally attributed to changes in the character and activity of the gonadotrophic and ovarian hormones which follow ovulation. Certainly these changes could account for most of the luteal appearances in the reproductive system, but they do not explain the great variety of disorders (Geiringer, 1951), the emotional instability (Stieglitz and Kimble, 1949; Morton, 1950), and the commission of violent crimes (Cooke, 1945) which are hazards of the luteum. Nor do they explain the acceleration in heart rate (MacKinnon, 1954a), the neutrophilia (MacKinnon, 1953), the lymphocytopenia (MacKinnon, 1953), the eosinopenia (Döring and Feustel, 1954), and the suppression of digital sweating (MacKinnon, 1954b) which occur at that time. These features are, however, all explicable in terms of altered suprarenal cortical activity.

\section{Present Investigation}

In order to obtain direct evidence of this activity suprarenal glands and uteri were collected from women of reproductive age with a view to comparing, anatomically and histochemically, the cortices of those dying in the follicular phase with those dying in the luteal phase of the cycle. In two and a half years specimens from 47 successive postmortem examinations-accident, suicide, and disease (see Table)-were collected from a London mortuary dealing

Cause of Death in 47 Women of Reproductive Age

\begin{tabular}{|c|c|c|}
\hline Suicide & Accident & Disease \\
\hline $\begin{array}{l}14 \text { carbon monoxide } \\
6 \text { barbiturate } \\
1 \text { cyanide } \\
1 \text { aspirin } \\
1 \text { hanging }\end{array}$ & $\begin{array}{l}5 \text { fractured skull } \\
3 \text { carbon monoxide } \\
1 \text { electrocution }\end{array}$ & $\begin{array}{l}3 \text { pulmonary embolism } \\
2 \text { coronary thrombosis } \\
2 \text { peritonitis } \\
2 \text { chronic heart } \\
2 \text { subarachnoid haem. } \\
1 \text { pur bronchitis } \\
1 \text { chronic anaemia } \\
1 \text { angioneurotic oedema } \\
1 \text { status epilepticus }\end{array}$ \\
\hline
\end{tabular}

with coroners' cases. The time of death in relation to the menstrual cycle was determined by means of endometrial histology, by which deaths were allocated to the follicular phase or to the early, middle, or late stages of the luteal phase, the duration of the luteal subdivisions being two, seven, and five days respectively (Lloyd, 1951). It was found (see Chart) that only two deaths had taken place in the follicular phase and that the total number of deaths, and also the deaths from suicide, accident, and disease separately, were more numerous in the middle than in the combined early and late parts of the luteum.

Glands obtained from cases of death from disease were not regarded as eligible for comparison. Of the cases of suicide and accident (see Table) only one, a case of carbon monoxide poisoning, was found to have occurred in the follicular phase (see Chart). Its cortex was slightly smaller

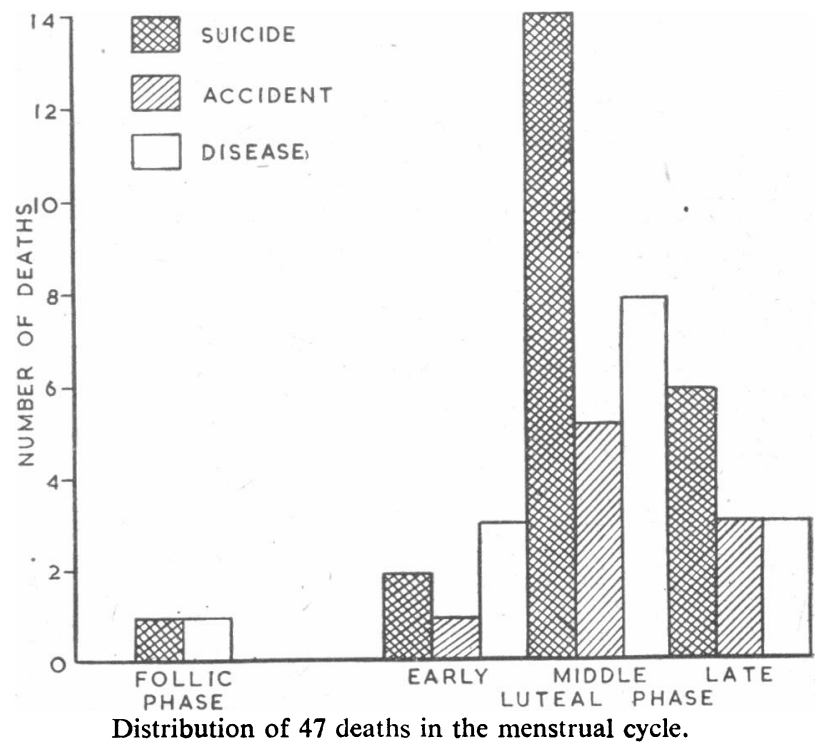

and appeared to be less active in Sudan IV and digitonin sections than the average luteal cortex, but the comparison is in no way significant, and at the present rate of collection some years may elapse before a significant one can be made.

However, the accompanying chart provides such clear evidence that suicides, fatal accidents, and deaths from disease are commoner in the luteal than in the follicular phase of the menstrual cycle that it seemed desirable to publish the facts so far found, to draw the attention of practitioners to the hazards of the cycle. For it would seem reasonable to suggest that highly strung women and those suffering from chronic disease should be warned of the hazards and advised to take more care and rest, and that planned operations, especially of the major variety-for example, valvotomyshould be carried out in the follicular phase of the cycle.

It is a pleasure to acknowledge the co-operation we have had, and continue to have, from Dr. Francis Camps.

\section{REFERENCES}

Cooke, W. R. (1945). Amer. J. Obstet. Gynec., 49, 457

Döring, G. K., and Feustel, E. (1954). Arch. Gynäk., 184, 522.

Geiringer, E. (1951). J. Obstet. Gynaec. Brit. Emp., 58, 1010.

Lloyd, O. C. (1951). In Recent Advances in Clinical Pathology, edited by S. C. Dyke, 2nd ed., p. 425 . Churchill, London.

Mackinnon, I. L. (1953), J. Obstet. Gynaec, Brit. Emp., 60, 878. - (1954a). Ibid., 61, 109.

Mackinnon, P. C. B. (1954b). Ibid., 61, 390.

Morton, J. I. (1950), Amer. J. Obstet. Gynec., 60, 343.

Stieglitz, E. J., and Kimble, S. T. (1949). Amer. J. med. Sci., 218, 616.

There are more than 5,000 alien physicians from 83 different countries now in training in the United States, of whom about 1 in every 8 is a woman, and they constitute " up to one-fourth of the total of resident staffs on duty in the hospitals of this country," writes Dr. CARL BEARSE, of the New England Hospital, Boston, in a recent guest editorial in the Journal of the American Medical Association (February 18, p. 562 ). Dr. Bearse stresses the importance of the visiting foreign doctor, with his wide contacts among patients in his own country, as a potential promoter of international friendship. At the New England Hospital foreign doctors are given a month's course of "indoctrination and orientation " before their medical training begins. 